\title{
Revisitando Rondônia: história, memória e ciência
}

\author{
Revisiting Rondônia: history, \\ memory and science
}

\author{
Adriana T. A. Martins Keuller \\ Mestre em História Social - PUC-Rio \\ Av. Alfredo Whately 365/201 - bloco A \\ Campos Elisios \\ Resende - RJ - Brasil \\ adriana.keuller@gmail.com
}

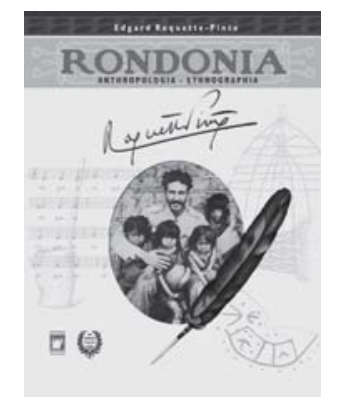

Roquette-Pinto, E. Rondônia. Rio de Janeiro: Ed. Fiocruz, 2005. 252p.
$\mathrm{M}$ omento de celebração! Depois de vinte anos o livro Rondônia, de Edgard Roquette-Pinto, volta a ser publicado, em uma parceira da Academia Brasileira de Letras com a Fiocruz, encerrando a seqüência de homenagens, promovidas por ambas as instituições, aos cinqüenta anos da morte do autor.

A bela edição resgata o formato da primeira, publicada em Archivos do Museu Nacional, periódico editado pela instituição em que Edgard Roquette-Pinto fez carreira e consagrou-se profissionalmente. O prefácio e a introdução colocam o leitor a par da trajetória pessoal e profissional do autor, e associa a pesquisa científica então praticada ao contexto intelectual e político da época.

Fruto de observações e descrições dos índios da Serra do Norte, em território pertencente aos atuais estados de Mato Grosso e Rondônia, o livro relata a viagem de Roquette-Pinto por cinco meses, em 1912, como membro integrante da Comissão Rondon. Se não fosse por esse engajamento, diz o autor que sua empreitada teria levado mais de um ano (p.200). A Comissão teve por missão implantar linhas telegráficas do Mato Grosso ao Amazonas - a chamada Estrada Rondon, cujo mapa encontra-se no livro - com o fim último de integrar à nação aquela região então isolada e pouco conhecida, por meio do acesso ao 'progresso', à 'ciência' e à 'civilização'. Simultaneamente, expedições exploratórias foram realizadas naqueles territórios e resultaram em uma série de levantamentos e estudos geológicos, botânicos, geográficos, zoológicos, antropológicos e etnográficos.

Misto do pensar e do sentir, Rondônia reflete a prática social e científica do autor, documentada sob a forma de um diário de campo que congregou registros em diversos suportes, essenciais para a realização do projeto (p.109). Pensando-a como um documento/monumento de Jacques Le Goff, a obra, mais do que um registro, memoriza outros monumentos, entre eles a paisagem natural da região e os objetos da cultura material dos índios - que hoje integram o acervo do Museu Nacional e que são representados, na edição, por ilustrações feitas pelo conservador de arqueologia do Museu, A. Childe - e da cultura imaterial daqueles povos, como as canções reproduzidas em fonogramas pelo professor Astolpho Tavares, os mitos e o vocabulário, apresentados ao final do livro. 
Parte integrante de uma 'memória científica', Rondônia espelha a tríade de elementos que a compõem: o cientista, a instituição e a disciplina. Na contracapa da edição original, mais informações sobre seu autor: professor do Museu Nacional do Rio de Janeiro e da Academia de Altos Estudos; segundo secretário do Instituto Histórico e Geográfico Brasileiro e da Sociedade Brasileira de Ciências; docente da Faculdade de Medicina e da Escola Normal e, posteriormente, membro da Academia Brasileira de Letras.

"Escrevo para documentar e divulgar, para arquivar e servir" (p.63). De fato, Roquette-Pinto, percebendo a importância da mais interessante população 'selvagem' do mundo - os Nambiquaras -, esperava que suas notas servissem, não para satisfazer pretensões literárias, "para quem toma um livro a fim de se recrear", mas sim para recordar o "cliché cru" que ele tirou: "um instantâneo da situação social, antropológica e etnográfica dos índios da Serra do Norte, antes que principiasse o trabalho de decomposição que nossa cultura vai neles processando" (p.xiv).

Indignação, excitação, preocupação são palavras que expressam bem os sentimentos do cientista ao longo do texto. Indignação com a situação social dos sertanejos, por ele caracterizados como "pequenos e magros, enfermos e inésticos", mas fortes, que "vivem trabalhando, trabalhados pela doença" (p.44). Nesse trecho do livro o autor dialoga com o relatório Penna-Neiva, de 1912, e até mesmo com Euclides da Cunha, que se refere aos "sertanejos pequenos e magros mas fortes que vivem trabalhando". Aos olhos do médico não passaram despercebidas doenças que grassavam entre sertanejos e índios e que foram, posteriormente, discutidas com a comunidade científica, a exemplo de um tipo de dermatose levado à Sociedade Brasileira de Dermatologia em 1915.

Roquette-Pinto mostra excitação ao perceber sinais de proximidade dos Nambiquaras, após um mês de viagem pelo sertão. Na descrição dos primeiros contatos, os índios, entre falatórios e gritarias, expressam-se em uma explosão de alegria. E o cientista? Envolto naquele quadro de magia, Roquette-Pinto mantém-se insone em sua rede: “Dormir, naquela noite inesquecível em que a sorte me tinha feito surpreender, vivo e ativo, o 'homem da idade da pedra' recluso no coração do Brasil ..." (p.108). A preocupação do autor, por sua vez, concentra-se na situação social dos índios diante do debate sobre a construção da nação brasileira, quando ele aponta o papel social dos antropólogos: "proteger, sem procurar dirigir, nem aproveitar essa gente" (p.200; grifos do autor).

A obra Rondônia consolida, também, a relação de Edgard RoquettePinto com o Museu Nacional do Rio de Janeiro, instituição à qual pertenceu como professor e chefe da 4 a Seção de Antropologia e Etnografia e, posteriormente, como diretor, nos 42 anos em que ali atuou. A coleta científica que realizou permitiu formar uma grande, única e inédita coleção para a instituição. Vale lembrar que as ilustrações desses objetos, no livro, apresentam a catalogação do Museu, e que na obra são expressos agradecimentos a funcionários como o diretor Bruno Lobo e os colegas Domingos Sérgio de Carvalho, Santos Lahera y Castillo e Alberto Childe. 
Por último, é importante observar que a narrativa de RoquettePinto reflete a maneira como esse autor compreendia a ciência antropológica e como ela era praticada naquela época. Exercida por médicosantropólogos, essa prática científica seguia os ensinamentos da escola francesa de Broca e de Topinard. Associada aos estudos da medicina e derivada da história natural, preocupava-se em coletar, descrever e classificar características físico-anatômicas dos tipos humanos, as quais eram anotadas nas chamadas fichas antropométricas. Uma série de tabelas, desenhos, impressões digitais e retratos falados, ao longo do livro, testemunham o princípio de raça como a variabilidade biológica dos tipos humanos.

A reedição de Rondônia é, portanto, um ato de comemoração científica, pois o livro nos faz recordar um tempo e uma prática social e científica. Além das denúncias sobre problemas e contrastes do Brasil no início do século XX, a obra nos mostra como era exercida uma antropologia cuja prática hoje denominamos antropologia física ou biológica. 